\title{
Erratum to clinical utility of targeted gene enrichment and sequencing technique in the diagnosis of adult hereditary spherocytosis
}

\author{
Jun Xue, Qing He, Xiaojing Xie, Ailing Su, Shibin Cao \\ Department of Hematology, Nanjing First Hospital, Nanjing Medical University, Nanjing 210006, China \\ Correspondence to: Jun Xue. Department of Hematology, Nanjing First Hospital, Nanjing Medical University, Nanjing 210006, China. \\ Email: xuejun64@sina.com.
}

doi: $10.21037 /$ atm.2019.12.120

View this article at: http://dx.doi.org/10.21037/atm.2019.12.120

Erratum to: Ann Transl Med 2019;7:527

Clinical utility of targeted gene enrichment and sequencing technique in the diagnosis of adult bereditary spherocytosis

In the article entitled "Clinical utility of targeted gene enrichment and sequencing technique in the diagnosis of adult hereditary spherocytosis" (1), the affiliation of all authors should be corrected as follow: Department of Hematology, Nanjing First Hospital, Nanjing Medical University, Nanjing 210006, China.

We regret the errors.

\section{References}

1. Xue J, He Q, Xie X, et al. Clinical utility of targeted gene enrichment and sequencing technique in the diagnosis of adult hereditary spherocytosis. Ann Transl Med 2019;7:527.

Cite this article as: Xue J, He Q, Xie X, Su A, Cao S. Erratum to clinical utility of targeted gene enrichment and sequencing technique in the diagnosis of adult hereditary spherocytosis. Ann Transl Med 2019;7(Suppl 8):S391. doi: 10.21037/ atm.2019.12.120 